INTERNATIONAL JOURNAL OF MULTIDisciplinARY RESEARCH AND ANALYSis

ISSN(print): 2643-9840, ISSN(online): 2643-9875

Volume 04 Issue 02 February 2021

DOI: 10.47191/ijmra/v4-i2-13, Impact Factor: 6.072

Page No.- 193-201

\title{
Effect of the Demographic of Covid-19 on Different Countries; Using the USA for Comparism
}

\author{
Joseph Oyepata Simeon ${ }^{1}$, Builders Modupe ${ }^{2}$, Joseph Opeyemi Tosin ${ }^{3}$, Famojuro Tayo Ibukun ${ }^{4}$, \\ Ogira Johnson Ogwuche ${ }^{5}$, Moses Femi Daniel ${ }^{6}$, Musa Tabitha Lubo ${ }^{7}$ \\ 1,2Department of Pharmacology and Toxicolology, Faculty of Pharmaceutical Sciences, Bingham University, Nasarawa State, \\ Nigeria \\ ${ }^{3}$ Department of Pharmacy, University College Hospital, Ibadan, Oyo State, Nigeria \\ ${ }^{4}$ Department of Pharmacognosy, Faculty of Pharmaceutical Sciences, Bingham University, Nasarawa State, Nigeria \\ ${ }^{5}$ Department of Pharmaceutical Chemistry, Faculty of Pharmaceutical Sciences, Bingham University, Nasarawa State, Nigeria \\ ${ }^{6}$ May Institute Behavioural Health Services, Boston Massachusetts, USA \\ ${ }^{7}$ Department of Pharmacognosy, Faculty of Pharmacy, Gombe State University, Gombe State, Nigeria
}

\begin{abstract}
Coronavirus disease 2019 (COVID-19) is a contagious disease caused by severe acute respiratory syndrome coronavirus. The virus that causes COVID-19 spreads mainly when an infected person is in close contact with another person. The aim of this study is to determine the effect of COVID-19 on different countries, using USA as comparism factor. Ninety four countries were selected based on their continents, countries and cases of infection. Data from each country were obtained from United Nations Geoscheme and WHO and were analyzed and compared to that of the United State of America (USA).Data analyzed revealed that most countries in Africa appears to be least affected by the virus. Data also revealed that many countries have been able to understand and manage the spread and infectivity of the virus compared to the USA. Result from the study also showed that the many countries have been able to improve on managing the infection when compared to USA mortality. This may be due to among other factors a more robust immune response, herd immunity and united approach in the management of the disease. The result also helps to provide insight as to how significant developing and providing vaccine may be to this part of the world. Result from the study suggests that while Africa has a better immunity for the virus, there seems to be improvement the management of disease by other continent.
\end{abstract}

KEYWORD: Africa, USA, COVID-19, countries, continent

\section{INTRODUCTION}

Coronaviruses are members of the subfamily Orthocoronavirinae, in the family Coronaviridae, order Nidovirales, and realm Riboviria [1,2]. They are enveloped viruses with a positivesense single-stranded RNA genome and a nucleocapsid of helical symmetry. The corona virus genome consists of a single strand of positive-sense RNA (ribonucleic acid). Coronaviridae is generally considered to contain two genera, Corona virus and Toro virus, which differ in nucleocapsid morphology, the former being helical and the latter being tubular [3]. Corona viruses are important agents of gastrointestinal disease in humans, poultry, and bovines. In humans, a species known as SARS corona virus (or Severe acute respiratory syndrome corona virus) causes a highly contagious respiratory disease that is characterized by symptoms of fever, cough, and muscle ache, often with progressive difficulty in breathing. The virus emerged in humans in 2002; it likely jumped to humans from an animal reservoir, believed to be horseshoe bats $[4,5,6]$. The ability of SARS corona virus to jump to humans undoubtedly required genetic changes in the virus. These changes are suspected to have occurred in the palm civet, since the SARS virus present in horseshoe bats is unable to infect human's directly9. Corona viruses are a group of RNA viruses that cause diseases in mammals and birds. In humans and birds, they cause respiratory tract infections that can range from mild to lethal [7]. The virus that causes COVID-19 spreads mainly when an infected person is in close contact with another person [8]. Small droplets and aerosols containing the virus can spread from an infected person's nose and mouth as they breathe, cough, sneeze, 


\section{Effect of the Demographic of Covid-19 on Different Countries; Using the USA for Comparism}

sing, or speak. Other people are infected if the virus gets into their mouth, nose or eyes. The virus may also spread via contaminated surfaces, although this is not thought to be the main route of transmission [9]. The exact route of transmission is rarely proven conclusively, ${ }^{[20]}$ but infection mainly happens when people are near each other for long enough. It can spread as early as two days before infected persons show symptoms, and from individuals who never experience symptoms. People remain infectious for up to ten days in moderate cases, and two weeks in severe cases. Various testing methods have been developed to diagnose the disease. The standard diagnosis method is by real-time reverse transcription polymerase chain reaction ( $r R T-P C R$ ) from a nasopharyngeal swab [10].

Many larger droplets rapidly fall to the ground, however some can be suspended in air as aerosols, especially in indoor spaces[11]. It may also be transmitted via contaminated surfaces, although this has not been conclusively demonstrated [11]. It can spread for up to two days prior to symptom onset, and from people who are asymptomatic [12]. People remain infectious in moderate cases for 7-12 days, and up to two weeks in severe cases [13].

Viruses constantly change through mutation, and new variants of a virus are expected to occur over time. Sometimes new variants emerge and disappear. Other times, new variants emerge and persist. Multiple variants of the virus that causes COVID-19 have been documented in the United States and globally during this pandemic. In the United Kingdom (UK), a new variant has emerged with an unusually large number of mutations. In South Africa, another variant has emerged independently of the variant detected in the UK. Another variant recently emerged in Nigeria $[13,14,15]$.

The number of new COVID-19 cases in the months of July and August, 2020, declined rapidly. This trend reversed during the month of October with many countries now experiencing either their first major increase in the number of new COVID-19 cases or their second wave of the pandemic $[15,16]$. The second wave of the disease has been a focus of concern due to change in weather and mutated strain of the virus discovered in some countries. There is the need to understand this surge with the virulent and spreading ability of the newly mutated strain of the virus. The aim of this study is to determine the effect of covid-19 on different region and countries of the world using the USA as a comparism factor. The aim of this study is to determine the effect of COVID19 on different region and countries of the world using the USA as a comparism factor.

\section{MATERIAL AND METHODS}

Ninety four (94) countries from different continent and regions of the world were selected from each continent and based on COVID-19 cases in each country. The list of countries and territories with their continental regional classification is based on the United Nations Geoscheme and WHO. Sources and data used were provided under Latest Updates from WHO/World meter's on January 11, 2021[17]. Data obtained for each country was analyzed and compared to that of the United State of America (USA). USA was used as a Comparism Factor (CF) because it has one of the best healthcare systems in the world and high COVID-19 cases. Subsequent examination of associations between the proportion of COVID-19 cases, recovery and deaths of each country to the United State of America was carried out. All data used in these analyses are from publicly available data sets.

\subsection{Statistical analysis}

Parameters such as total incidences/cases, total deaths and total recovered of countries was compared against figures and values obtained for USA. Bivariate analysis was done with Chi-square test to compare proportions for variables. In reporting these results, country-level characteristics are scaled to represent a comparison of two countries similar in all other respects. Thus, rate ratios greater than one means that higher levels of a given characteristic are associated with higher rates of COVID-19 cases or deaths, while rate ratios less than one means that lower levels of a given characteristic are associated with lower rates of COVID-19 cases or deaths.

\section{RESULT}

\subsection{Infectious, recovery and mortality rate of COVID-19 based on country}

Data analyzed revealed that with exception of South Africa, Africa appears to be least affected by the virus. America and Europe are most affected by the disease. Result also showed most countries of the world have considerable number of affected citizens. When compared to USA, African countries are among the least with infection, more recovery and lesser number of deaths. Asian continent is mildly affected while Americans and Europeans are most affected when compare to the index value of USA. 
Effect of the Demographic of Covid-19 on Different Countries; Using the USA for Comparism

Table 1: Infectious and mortality rate of COVID-19 relative to the USA based on countries

\begin{tabular}{|c|c|c|c|c|c|c|c|c|}
\hline \multirow[b]{2}{*}{ \# } & \multirow{2}{*}{$\begin{array}{l}\text { Country, } \\
\text { Other }\end{array}$} & \multirow{2}{*}{$\begin{array}{l}\text { Total } \\
\text { Cases }(\mathrm{A})\end{array}$} & \multirow{2}{*}{\begin{tabular}{|l|} 
Total \\
Deaths (B) \\
\end{tabular}} & \multirow[b]{2}{*}{ Population (D) } & & & & \multirow[b]{2}{*}{ G/0.115 } \\
\hline & & & & & \multirow{2}{*}{$\begin{array}{l}\text { AX100/D } \\
\text { (E) }\end{array}$} & \multirow{2}{*}{$\begin{array}{l}\mathrm{BX} 100 / \mathrm{D} \\
(\mathrm{G})\end{array}$} & & \\
\hline 1 & USA & $22,917,334$ & 383,275 & $332,029,184$ & & & (I) & (J) \\
\hline 2 & India & $10,467,431$ & 151,198 & $1,387,160,324$ & 6.9 & 0.12 & 1 & 1 \\
\hline 3 & Brazil & $8,105,790$ & 203,140 & $213,357,846$ & 0.75 & 0.01 & 0.11 & 0.09 \\
\hline 4 & Russia & $3,425,269$ & 62,273 & $145,967,675$ & 3.8 & 0.1 & 0.55 & 0.83 \\
\hline 5 & UK & $3,072,349$ & 81,431 & $68,074,687$ & 2.35 & 0.04 & 0.34 & 0.37 \\
\hline 6 & France & $2,783,256$ & 67,750 & $65,350,084$ & 4.51 & 0.12 & 0.65 & 1.04 \\
\hline 7 & Turkey & $2,326,256$ & 22,807 & $84,817,409$ & 4.26 & 0.1 & 0.62 & 0.9 \\
\hline 8 & Italy & $2,276,491$ & 78,755 & $60,414,581$ & 2.74 & 0.03 & 0.4 & 0.23 \\
\hline 9 & Spain & $2,050,360$ & 51,874 & $46,764,390$ & 3.77 & 0.13 & 0.55 & 1.13 \\
\hline 10 & Germany & $1,929,353$ & 41,434 & $83,925,880$ & 4.38 & 0.11 & 0.64 & 0.96 \\
\hline 11 & Colombia & $1,786,900$ & 46,114 & $51,168,770$ & 2.3 & 0.05 & 0.33 & 0.43 \\
\hline 12 & Argentina & $1,722,217$ & 44,495 & $45,414,613$ & 3.49 & 0.09 & 0.51 & 0.78 \\
\hline 13 & South Africa & $1,231,597$ & 33,163 & $59,702,305$ & 1.52 & 0.07 & 0.22 & 0.58 \\
\hline 14 & Ukraine & $1,119,314$ & 19,835 & $43,593,745$ & 2.06 & 0.06 & 0.3 & 0.48 \\
\hline 15 & Peru & $1,035,184$ & 38,280 & $33,213,393$ & 2.57 & 0.05 & 0.37 & 0.4 \\
\hline 16 & Netherlands & 872,847 & 12,361 & $17,154,972$ & 3.12 & 0.12 & 0.45 & 1 \\
\hline 17 & Indonesia & 836,718 & 24,343 & $275,048,313$ & 5.09 & 0.07 & 0.74 & 0.63 \\
\hline 18 & Israel & 494,338 & 3,671 & $9,197,590$ & 0.23 & 0 & 0.03 & 0.04 \\
\hline 19 & Philippines & 489,736 & 9,416 & $110,348,422$ & 5.37 & 0.04 & 0.78 & 0.35 \\
\hline 20 & Sweden & 489,471 & 9,433 & $10,132,561$ & 0.44 & 0.01 & 0.06 & 0.07 \\
\hline 21 & Portugal & 483,689 & 7,803 & $10,180,895$ & 4.83 & 0.09 & 0.7 & 0.81 \\
\hline 22 & Switzerland & 477,983 & 8,267 & $8,688,062$ & 4.75 & 0.08 & 0.69 & 0.67 \\
\hline 23 & Morocco & 452,532 & 7,743 & $37,140,976$ & 5.5 & 0.1 & 0.8 & 0.83 \\
\hline 24 & Austria & 382,258 & 6,747 & $9,033,579$ & 1.22 & 0.02 & 0.18 & 0.18 \\
\hline 25 & Saudi Arabia & 363,809 & 6,291 & $35,098,649$ & 4.23 & 0.07 & 0.61 & 0.65 \\
\hline 26 & Slovenia & 139,707 & 3,022 & $2,079,090$ & 0.79 & 0.03 & 0.11 & 0.24 \\
\hline 27 & Malaysia & 135,992 & 551 & $32,584,252$ & 6.72 & 0.15 & 0.97 & 1.26 \\
\hline 28 & Oman & 130,780 & 1,508 & $5,174,335$ & 0.42 & 0 & 0.06 & 0.01 \\
\hline 29 & Myanmar & 130,604 & 2,846 & $54,602,598$ & 2.53 & 0.03 & 0.37 & 0.25 \\
\hline 30 & Ethiopia & 128,316 & 1,994 & $116,448,962$ & 0.24 & 0.01 & 0.03 & 0.05 \\
\hline 31 & Honduras & 127,945 & 3,273 & $9,987,329$ & 0.11 & 0 & 0.02 & 0.01 \\
\hline 32 & Venezuela & 116,610 & 1,061 & $28,393,088$ & 1.28 & 0.03 & 0.19 & 0.28 \\
\hline 33 & Paraguay & 115,733 & 2,405 & $7,178,667$ & 0.41 & 0 & 0.06 & 0.03 \\
\hline 34 & $\begin{array}{ll}\text { Bosnia } & \text { and } \\
\text { Herzegovina } & \\
\end{array}$ & 115,633 & 4,330 & $3,269,943$ & 1.61 & 0.03 & 0.23 & 0.29 \\
\hline 35 & Libya & 104,745 & 1,581 & $6,920,441$ & 3.54 & 0.13 & 0.51 & 1.15 \\
\hline 36 & Algeria & 102,144 & 2,807 & $44,266,190$ & 1.51 & 0.02 & 0.22 & 0.2 \\
\hline 37 & Nigeria & 100,087 & 1,358 & $208,804,573$ & 0.23 & 0.01 & 0.03 & 0.06 \\
\hline 38 & Kenya & 98,271 & 1,710 & $54,390,412$ & 0.05 & 0 & 0.01 & 0.01 \\
\hline 39 & Bahrain & 95,558 & 356 & $1,732,185$ & 0.18 & 0 & 0.03 & 0.03 \\
\hline 40 & China & 87,536 & 4,634 & $1,439,323,776$ & 5.52 & 0.02 & 0.8 & 0.18 \\
\hline
\end{tabular}


Effect of the Demographic of Covid-19 on Different Countries; Using the USA for Comparism

\begin{tabular}{|c|c|c|c|c|c|c|c|c|}
\hline 41 & North Macedonia & 86,494 & 2,622 & $2,083,329$ & 0.01 & 0 & 0 & 0 \\
\hline 42 & Singapore & 58,929 & 29 & $5,874,643$ & 2.21 & 0.04 & 0.32 & 0.38 \\
\hline 43 & Ghana & 55,772 & 336 & $31,412,276$ & 1 & 0 & 0.15 & 0 \\
\hline 44 & Norway & 55,474 & 472 & $5,443,630$ & 0.18 & 0 & 0.03 & 0.01 \\
\hline 45 & Afghanistan & 53,584 & 2,301 & $39,386,438$ & 1.02 & 0.01 & 0.15 & 0.08 \\
\hline 46 & Montenegro & 52,431 & 725 & 628,108 & 0.14 & 0.01 & 0.02 & 0.05 \\
\hline 47 & Latvia & 49,568 & 849 & $1,875,051$ & 8.35 & 0.12 & 1.21 & 1 \\
\hline 48 & El Salvador & 48,905 & 1,428 & $6,503,523$ & 2.64 & 0.05 & 0.38 & 0.39 \\
\hline 49 & Sri Lanka & 48,380 & 232 & $21,460,786$ & 0.75 & 0.02 & 0.11 & 0.19 \\
\hline 50 & Luxembourg & 47,984 & 533 & 631,324 & 0.23 & 0 & 0.03 & 0.01 \\
\hline 51 & Finland & 38,790 & 586 & $5,545,285$ & 7.6 & 0.08 & 1.1 & 0.73 \\
\hline 52 & Uganda & 37,742 & 301 & $46,490,498$ & 0.7 & 0.01 & 0.1 & 0.09 \\
\hline 53 & Estonia & 33,805 & 287 & $1,327,008$ & 0.08 & 0 & 0.01 & 0.01 \\
\hline 54 & Australia & 28,614 & 909 & $25,655,736$ & 2.55 & 0.02 & 0.37 & 0.19 \\
\hline 55 & Namibia & 28,259 & 254 & $2,565,029$ & 0.11 & 0 & 0.02 & 0.03 \\
\hline 56 & Zambia & 27,728 & 469 & $18,651,837$ & 1.1 & 0.01 & 0.16 & 0.09 \\
\hline 57 & Cyprus & 27,350 & 148 & $1,212,003$ & 0.15 & 0 & 0.02 & 0.02 \\
\hline 58 & Cameroon & 26,848 & 448 & $26,890,505$ & 2.26 & 0.01 & 0.33 & 0.11 \\
\hline 59 & Uruguay & 26,186 & 256 & $3,480,107$ & 0.1 & 0 & 0.01 & 0.01 \\
\hline 60 & Ivory Coast & 23,750 & 139 & $26,718,994$ & 0.75 & 0.01 & 0.11 & 0.06 \\
\hline 61 & Sudan & 23,316 & 1,468 & $44,383,875$ & 0.09 & 0 & 0.01 & 0 \\
\hline 62 & Mozambique & 21,939 & 192 & $31,711,045$ & 0.05 & 0 & 0.01 & 0.03 \\
\hline 63 & Zimbabwe & 21,477 & 507 & $14,976,653$ & 0.07 & 0 & 0.01 & 0.01 \\
\hline 64 & Senegal & 21,245 & 465 & $16,973,801$ & 0.14 & 0 & 0.02 & 0.03 \\
\hline 65 & DRC & 19,496 & 619 & $90,975,443$ & 0.13 & 0 & 0.02 & 0.02 \\
\hline 66 & Angola & 18,193 & 416 & $33,396,916$ & 0.02 & 0 & 0 & 0.01 \\
\hline 67 & Madagascar & 18,001 & 267 & $28,062,073$ & 0.05 & 0 & 0.01 & 0.01 \\
\hline 68 & Sierra Leone & 2,834 & 77 & $8,061,886$ & 9.41 & 0.05 & 1.36 & 0.41 \\
\hline 69 & San Marino & 2,628 & 64 & 33,969 & 0.04 & 0 & 0.01 & 0.01 \\
\hline 70 & Chad & 2,537 & 107 & $16,670,971$ & 7.74 & 0.19 & 1.12 & 1.64 \\
\hline 71 & Guinea-Bissau & 2,478 & 45 & $1,992,284$ & 0.02 & 0 & 0 & 0.01 \\
\hline 72 & Liechtenstein & 2,340 & 49 & 38,186 & 0.12 & 0 & 0.02 & 0.02 \\
\hline 73 & New Zealand & 2,222 & 25 & $5,002,100$ & 6.13 & 0.13 & 0.89 & 1.12 \\
\hline 74 & Yemen & 2,104 & 611 & $30,169,331$ & 0.04 & 0 & 0.01 & 0 \\
\hline 75 & Liberia & 1,779 & 83 & $5,119,748$ & 0.01 & 0 & 0 & 0.02 \\
\hline 76 & Eritrea & 1,556 & 6 & $3,572,235$ & 0.03 & 0 & 0.01 & 0.01 \\
\hline 77 & Sint Maarten & 1,555 & 27 & 43,132 & 0.04 & 0 & 0.01 & 0 \\
\hline 78 & Vietnam & 1,514 & 35 & $97,800,776$ & 3.61 & 0.06 & 0.52 & 0.54 \\
\hline 79 & Burundi & 986 & 2 & $12,074,788$ & 2.55 & 0.02 & 0.37 & 0.13 \\
\hline 80 & Barbados & 878 & 7 & 287,562 & 0.01 & 0 & 0 & 0 \\
\hline 81 & Taiwan & 834 & 7 & $23,839,634$ & 0.31 & 0 & 0.04 & 0.02 \\
\hline 82 & Bhutan & 813 & 1 & 776,085 & 0 & 0 & 0 & 0 \\
\hline 83 & Papua New Guinea & 811 & 9 & $9,035,821$ & 0.1 & 0 & 0.02 & 0 \\
\hline 84 & Diamond Princess & 712 & 13 & & 0.01 & 0 & 0 & 0 \\
\hline 85 & Bermuda & 652 & 12 & 62,156 & - & - & - & - \\
\hline
\end{tabular}


Effect of the Demographic of Covid-19 on Different Countries; Using the USA for Comparism

\begin{tabular}{|l|l|l|l|l|l|l|l|l|}
86 & Faeroe Islands & 646 & 1 & 48,961 & 1.05 & 0.02 & 0.15 \\
\hline 87 & Mauritius & 539 & 10 & $1,272,887$ & 1.32 & 0 & 0.17 \\
\hline 88 & Seychelles & 531 & 1 & 98,669 & 0.04 & 0 & 0.19 & 0.01 \\
\hline 89 & Tanzania & 509 & 21 & $60,619,149$ & 0.54 & 0 & 0.01 \\
\hline 90 & Saint Lucia & 438 & 5 & 184,071 & 0 & 0 & 0 & 0.01 \\
\hline 91 & Isle of Man & 396 & 25 & 85,271 & 0.24 & 0 & 0 & 0.03 \\
\hline 92 & Cambodia & 392 & & $16,840,653$ & 0.46 & 0.03 & 0.07 & 0.25 \\
\hline 93 & Cayman Islands & 359 & 2 & 66,129 & 0 & 0 & 0 & 0 \\
\hline 94 & Dominica & 106 & & 72,081 & 0.38 & 0 & 0.05 & 0.03 \\
\hline
\end{tabular}

Sources and data used were provided under Latest Updates from WHO/World meter's on January 11, 2021

Figures obtained for USA were used as the comparism factor (CF), which is a ratio of figure obtained to the respective country population divided by the value obtained for USA.

Values of F1 and F2 represent case/incidence and mortality index.

Factor of more than 1 = very high infection and mortality index

Factor of approximately 1 = high infection and mortality index

Factor of $\leq 1$ but $\geq 0.5$ = moderately high infection and mortality index

Factor of $\leq 0.5$ but $\geq 0.1$ = low infection and mortality index

Factor of $<0.1=$ very low infection, mortality and recovery index

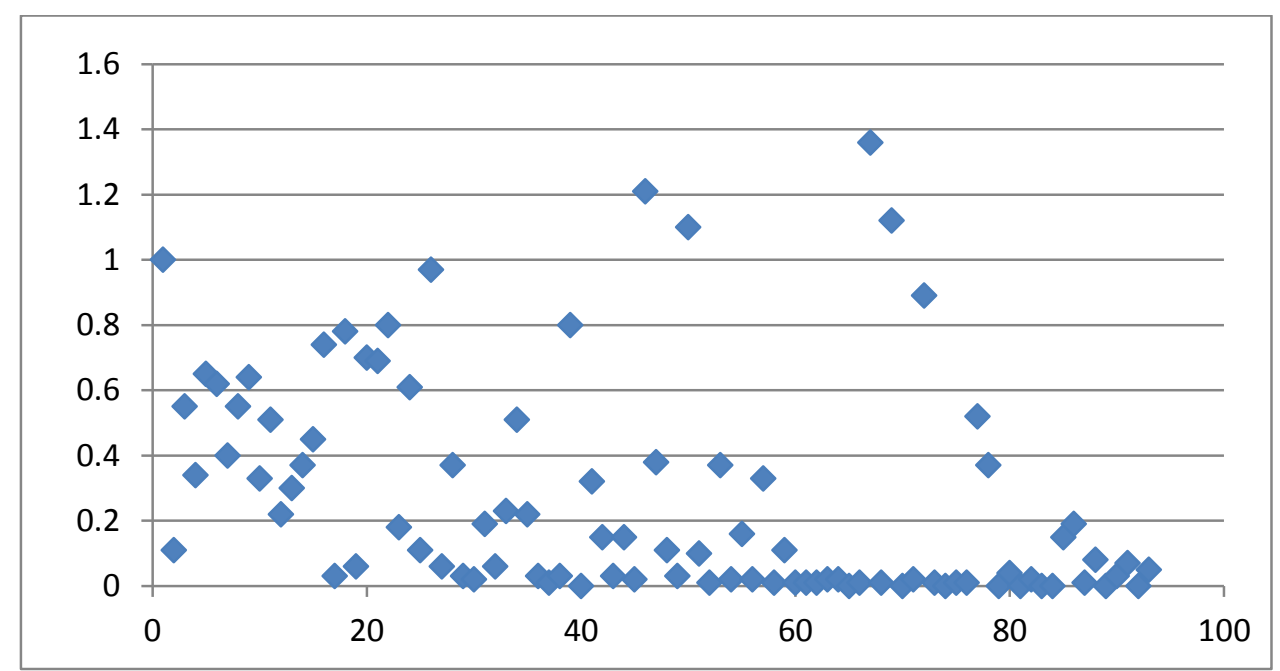

Figure 1: graph comparing infection per country relative to USA

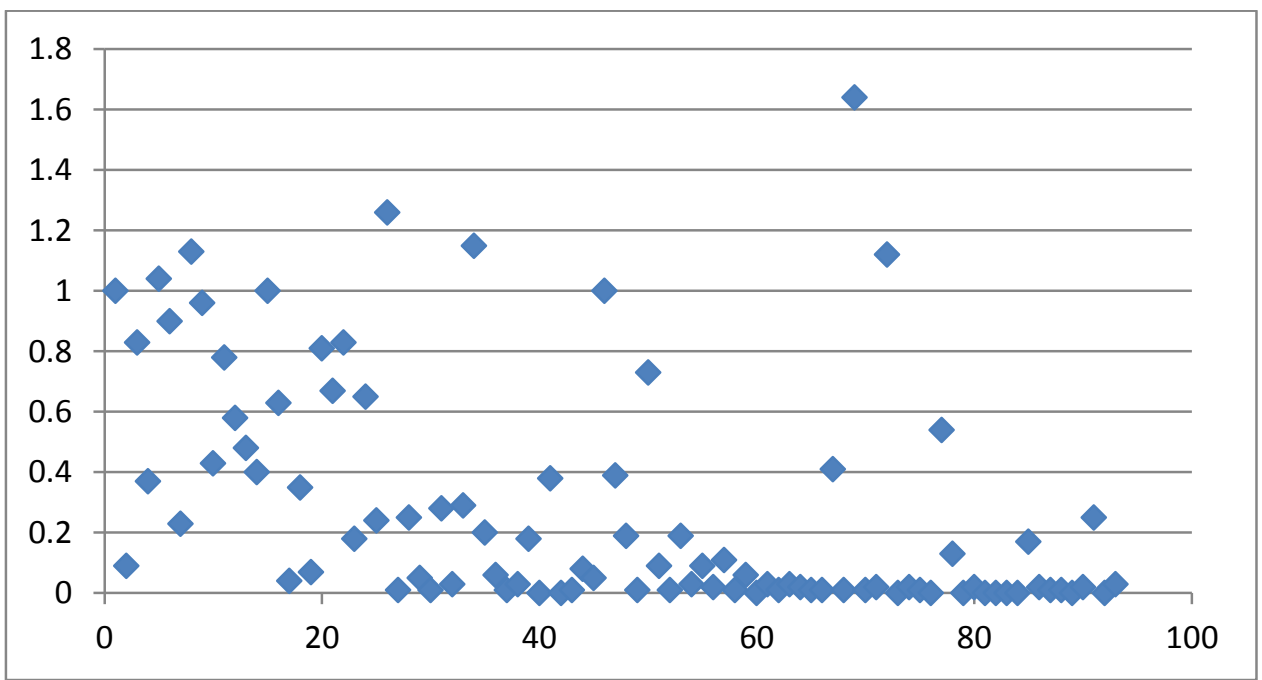

Figure 2: graph comparing death per country relative to USA 


\section{Effect of the Demographic of Covid-19 on Different Countries; Using the USA for Comparism}

\section{DISCUSSION}

COVID-19 infects people of all ages[18]. However, there are two main groups at a higher risk of developing severe disease: older people, and people with underlying comorbidities such as diabetes mellitus, hypertension, cardiorespiratory disorders, chronic liver diseases and renal failure [18]. The rates of hospitalization and death are less than $0.1 \%$ in children but increase to $10 \%$ or more in older patients [19]. COVID-19 has affected the world health wise and in economic terms [19]. It is apparent that scientist are yet to fully understand the virus with probable medications that can be used in it management. Luckily enough, vaccines have recently been developed by different countries and companies to protect against the disease. The high cost of vaccination has made it imperative to determine the distribution and availability of the vaccine across regions and countries based on relative urgency.

Mutations in the COVID-19 virus that was detected South Africa and the United Kingdom (and potentially Nigeria) in December, 2020, makes the virus significantly more transmissible and raising prospects that the second wave could become even more dispersed $[14,15,16,20]$. In South Africa, the mutated strain of the virus is dominant and driving the second wave $[15,17,20]$. Result of this study indicated that many western, Asian and African countries have an improved comparism factor (CF) to USA relative to previous work. The USA, which is the power and health giant of the world, appears to experience uncontrolled and spiral increase in infection and death rate when compared to other countries who have promptly and steadily applied measures to curb the spread and manage the disease. This may be due to genetics, environmental, political and/or racial division [7,21,22,23,24]. Compared to previous studies, most African and European countries have steadily improved on their indexes despite the second wave and mutated strain of the virus. This may be due to better understanding of the virus, united approach, herd immunity and previous (most probable childhood) exposure to similar or cross strain of the virus.

Africa is the least affected of all the continents. Africa is confronted by heavy burden of communicable and non-communicable diseases $[26,27,28,29]$. From the onset of viral outbreak, the World Health Organization (WHO) has rushed to beef up the ability of African countries to test for the virus and train health professionals in caring for people affected by it [30,31,32]. From the table above South Africa is the only African country with mild infection and mortality factor, while most African countries have very low infection and mortality factor. Most countries in Africa have a communal lifestyle compared to the isolation lifestyle of the western countries $[33,34,35]$. Hence, it is possible that a large proportion of Africans have been exposed to COVID-19 but few have presented visible symptoms or tested positive to the virus. Interestingly, Africa-American are the most hit among other Americans by this pandemic [36]. It is expected that due to the virus mode of transmission, the index value should be very high for African countries when compared to other countries. There have been several suggestions to explain why Africa appears to be less affected by the pandemic. These include notable difference in the population age pyramids of USA, European and African countries, slow or low testing rate, low records of hospital reporting the disease, relatively high temperature and high humidity and high consumption of antioxidant food/fruit substances [37]. Because of the density of the virus in tropical Africa, it cannot travel far [38]. Hence, the recommendation of two meters of social distancing rule does not apply because the virus cannot go far. Africans food contents also raised the diet factor. Africans also take a lot of phytomedicines which contains a lot of antioxidant. Thus, having a more robust immune response [39].

Evolutionary or adaptive immune response to the virus may also have immensely contributed to low infectious and mortality case in Africa. Since African-American population is more affected by COVID-19 when compared to other Americans in the USA $[4,11,40]$, it is unlikely to be genetic, but more likely related to the environment. A study showed that children in low- and middleincome countries experience a high incidence of infectious disease in their first years of life [15,41]. Babraham Institute in 2020, studied immune responses of African children compared to Dutch children. They found that the immune systems of African children develop faster than those of Dutch children [42]. Exposure to germs in childhood may have helped to strengthen the immune system and protect children from developing allergies, asthma and other infectious diseases, on subsequence exposure to the same/similar allergen/pathogen or cross allergen/pathogen. This supports the 'hygiene hypothesis [11,42,43], which contends that such diseases are more common in the developed world where the prevalence of antibiotics and antibacterial reduce children's exposure to microbes $[10,41,44]$. Thus, early exposure to some diseases in Africa may have resulted in a more robust innate and/or adaptive immune response. As a result countries in Africa are both vulnerable and potentially more resilient to the corona virus.

The immune system is a network of biological processes that protects an organism from diseases [10,33,45]. It detects and responds to a wide variety of pathogens, from viruses to parasitic worms, as well as cancer cells and objects such as wood splinters, distinguishing them from the organism's own healthy tissue. Many species have two major subsystems of the immune system. The innate immune system provides a preconfigured response to broad groups of situations and stimuli. The adaptive immune 


\section{Effect of the Demographic of Covid-19 on Different Countries; Using the USA for Comparism}

system provides a tailored response to each stimulus by learning to recognize molecules it has previously encountered. Both use molecules and cells to perform their functions $[7,21,35,46]$. The innate response is usually triggered when microbes are identified by pattern recognition receptors, which recognize components that are conserved among broad groups of microorganisms $[23,27,32,47]$, or when damaged, injured or stressed cells send out alarm signals, many of which are recognized by the same receptors as those that recognize pathogens $[30,35,44]$. Innate immune defenses are non-specific, meaning these systems respond to pathogens in a generic way [30,32,37,47]. This system does not confer long-lasting immunity against a pathogen. Cells in the innate immune system use pattern recognition receptors to recognize molecular structures that are produced by pathogens. ${ }^{[21]}$ They are proteins expressed, mainly, by cells of the innate immune system, such as dendritic cells, macrophages, monocytes, neutrophils and epithelial cells $[3,15,48]$ to identify two classes of molecules: pathogen-associated molecular patterns (PAMPs), which are associated with microbial pathogens, and damage-associated molecular patterns (DAMPs), which are associated with components of host's cells that are released during cell damage or cell death. The adaptive immune response is antigen-specific and requires the recognition of specific "non-self" antigens during a process called antigen presentation $[15,38,49]$. Antigen specificity allows for the generation of responses that are tailored to specific pathogens or pathogen-infected cells. The ability to mount these tailored responses is maintained in the body by "memory cells". Should a pathogen infect the body more than once, these specific memory cells are used to quickly eliminate it $[14,19,21,35,50]$.

\section{CONCLUSION}

COVID-19 is still a global pandemic that has affected several vital sector of the world. Recently vaccines have been developed by different countries and companies to protect against the disease. Although, great stride has been achieved, Scientist are still trying to fully understand the virus; it biological makeup, mode of infection and best possible treatment/approach. Many countries, particularly Africans, Asians and Europeans have made plausible gain in their comparism factor when compare to few months ago. This may be due to united approach and herd immunity among the populace. USA has an unimpressive result which may be due to genetic, environmental, political and racial division.

Also, this work agrees with previous study, Africa has been a responsible bed to several viral diseases, which include dengue fever, small pox, chicken pox, measles, Ebola, bump and polio disease. The body may have been immune or found a way to cope with same or likely related infection. This innate and adaptive mechanism may have resulted in positive response to similar or different viral infection including corona virus disease. Also, the communal system and poor health regulation African government would have allowed for rapid transmission of the virus from person(s) to person(s) within the shortest possible time. This means most Africans may have been exposed to the virus with few or no noticeable symptoms from which they may have recovered, while very few people have shown symptom to the disease. Therefore, there is need for COVID-19 antibody and antigen testing, which will reveal the true picture of who has been exposed than the current antigen testing which only provides active disease information. Like other continents, Africa needs vaccine, but vaccination may relatively not be an emergency when compared to western world because most individuals in Africa countries may have been naturally and unconsciously inoculated.

\section{RECOMMENDATION}

More studies and surveys need to be conducted to understand the virus infectivity and it significances to Africa and maybe the rest of the world.

\section{ACKNOWLEDGEMENT}

The authors wish to appreciate and thank everyone who has contributed to the success of this study. Special appreciation to United Nations Geo scheme and WHO for access to raw data per country was gotten.

\section{REFERENCES}

1) Virus Taxonomy. Release. International Committee on Taxonomy of Viruses (ICTV). March 2019. Archived from the original on 2018-03-04. Retrieved 2020-01-24

2) www.who.int/emergencies/diseases/novel-coronavirus-2020

3) Virus Taxonomy: Release". International Committee on Taxonomy of Viruses (ICTV). 2019.

4) Giaimo C. The Spiky Blob Seen Around the World. The New York Times. 2020. Page 1-12.

5) International Committee on Taxonomy of Viruses (ICTV). October 2018. Archived from the original on 2019-05-14. Retrieved 2020-01-24.

6) International Committee on Taxonomy of Viruses (ICTV). Retrieved 2020-01-24. 


\section{Effect of the Demographic of Covid-19 on Different Countries; Using the USA for Comparism}

7) Fan Y, Zhao K, Shi ZL, Zhou P. Bat Corona viruses in China. Viruses. 2019.11 (3): 210-223.

8) Cherry, J, Demmler-Harrison GJ, Kaplan SL.; Steinbach WJ, Hotez PJ. Feign and Cherry's Textbook of Pediatric Infectious Diseases. Elsevier Health Sciences. 2017. p. PT6615. ISBN 978-0-323-39281-5.

9) Woo PC, Huang Y, Lau SK, Yuen KY. Corona virus genomics and bioinformatics analysis. Viruses. 2010. 2 (8): $1804-20$.

10) Almeida JD, Berry DM, Cunningham CH, Hamre D, Hofstad MS, Mallucci L, Mclntosh K, Tyrrell DA . Virology: Corona viruses. Nature. 1968. 220 (5168): 265-278.

11) https://www.cdc.gov/coronavirus/2019-ncov/transmission/variant.html

12) Chen N, Zhou M, Dong X, Qu J, Gong F, Han Y, et al. "Epidemiological and clinical characteristics of 99 cases of 2019 novel coronavirus pneumonia in Wuhan, China: a descriptive study". Lancet. 2020. 395 (10223): 507-513

13) Symptoms of Coronavirus". U.S. Centers for Disease Control and Prevention (CDC). 13 May 2020. Archived from the original on 17 June 2020. Retrieved 18 June 2020.

14) ArcGIS. Johns Hopkins University. Retrieved 12 January 2021.

15) Q\&A on coronaviruses (COVID-19)". World Health Organization (WHO).

16) Nussbaumer-Streit B, Mayr V, Dobrescu Al, Chapman A, Persad E, Klerings I, et al. "Quarantine alone or in combination with other public health measures to control COVID-19: a rapid review". The Cochrane Database of Systematic Reviews. 2020. 4: CD013574.

17) https://www.worldometers.info/coronavirus/11 January 2021

18) Transmission of COVID-19". European Centre for Disease Prevention and Control. Retrieved 6 December 2020.

19) Ye $Q$, Wang B, Mao J. "The pathogenesis and treatment of the 'Cytokine Storm' in COVID-19". The Journal of Infection. 2020. 80 (6): 607-613.

20) Bénézit, François; Le Turnier, Paul; Declerck, Charles; Paillé, Cécile; Revest, Matthieu; Dubée, Vincent; Tattevin, Pierre. "Utility of hyposmia and hypogeusia for the diagnosis of COVID-19". The Lancet Infectious Diseases. 2020.20 (9): 1014-1015.

21) Furukawa NW, Brooks JT, Sobel J . "Evidence Supporting Transmission of Severe Acute Respiratory Syndrome Coronavirus 2 While Presymptomatic or Asymptomatic". Emerging Infectious Diseases. 2020. 26 (7).

22) https://reliefweb.int/report/world/analyzing-africa-s-second-wave-covid-19.

23) Litman GW, Cannon JP, Dishaw LJ. "Reconstructing immune phylogeny: new perspectives". Nature Reviews. Immunology. 2005. 5 (11): 866-79.

24) Joseph OS. and Joseph OT. Hepatoprotective activity of ethanol stem extract of Homalium letestui against thioacetamideinduced liver injury. The Nigerian Journal of Pharmacy. 2018. Vol. 52 (1). Page 67-74.

25) Joseph O. S., Jude E.O and Joseph O. T. Hepatoprotective activity of extract of Homalium Letestui stem against carbon tetrachloride-induced liver injury. Advance Herbal Medicine. 2018. Vol 4(4), Page 1-11.

26) Restifo NP, Gattinoni L. "Lineage relationship of effector and memory T cells". Current Opinion in Immunology. 2013. 25 (5): 556-63.

27) Kurosaki T, Kometani K, Ise W. "Memory B cells". Nature Reviews. Immunology. 2015. 15 (3): 149-59.

28) Boyton RJ, Openshaw PJ. "Pulmonary defences to acute respiratory infection". British Medical Bulletin. 2002.61 (1): 112.

29) Joseph OS, Joseph OT, Musa TL and Oyepata P J. Histological evaluation of the nephroprotective activity of the ethanol stem extracts of Homalium letestui in Gentamicin - induced albino rats injury, using various staining techniques. Global Scientific Journal. 2020. Volume 7, Issue 8. Page 1065-1087.

30) Joseph OS, Builders M., Emem EU and Joseph OT. Effect of ethanol leaf extract of Cassia angustifolia extracts on liver of wister rats. Global Scientific Journal. 2019. Volume 8, Issue 9. Page 1112-11120.

31) Joseph OS., Builders M, Emem EU and Joseph OT. Effect of ethanol leaf extract of cassia angustifolia extract on kidney of wister rats. Global Scientific Journal. 2019. Volume 8, Issue 9. Page 1023-1031.

32) Agerberth B, Gudmundsson GH. "Host antimicrobial defence peptides in human disease". Current Topics in Microbiology and Immunology. 2006. 306: 67-90.

33) Joseph O. T, Obianime. A. W., Siminialaye M. I., Joseph O. S., Anyanwu C. and Musa T. L. Clinical study on the effect of Moringa oleifera on serum level of glucose and triglyceride in subjects taken tenofovir, lamivudine and efavirenz combination regimen. European Scientific Journal. 2019. Vol.15, (.21). Page 280 -293.

34) Moreau JM, Girgis DO, Hume EB, Dajcs JJ, Austin MS, O'Callaghan RJ. "Phospholipase A(2) in rabbit tears: a host defense against Staphylococcus aureus". Investigative Ophthalmology \& Visual Science. 2001. 42 (10): 2347-54. 


\section{Effect of the Demographic of Covid-19 on Different Countries; Using the USA for Comparism}

35) Wertheim JO, Chu DK, Peiris JS, Kosakovsky Pond SL, Poon LL. A case for the ancient origin of corona viruses. Journal of Virology. 2013. 87 (12): 7039-45.

36) Novel Corona virus (2019-nCoV) situation reports - World Health Organization (WHO) 16) 2019 Novel Corona virus (2019nCoV) in the U.S. -. U.S. Centers for Disease Control and Prevention (CDC).

37) Novel corona virus (2019-nCoV) - Australian Government Department of Health 19)

38) Maimuna Majumder and Kenneth D. Mandl. Early Transmissibility Assessment of a Novel Corona virus in Wuhan, China Harvard University - Computational Health Informatics Program 2020.

39) Imperial College London. Report 3: Transmissibility of 2019-nCoV - 25, 2020.

40) Joseph OS, Builders M, Joseph OT, Zubairu SA, Musa T. and Oyepata p.j. Sub-acute toxicity study of ethanol leaf extract of Ocimum canum on the kidney of wistar rats. African Journal of Pharmaceutical Research \& Development. 2019. Vol. 11 No.1. Page 1-7.

41) Joseph OS, Builders M, Joseph OT, Zubairu SA, Musa T. and Oyepata PJ. Sub-acute toxicity study of ethanol leaf extract of Ocimum canum on brain, lungs, stomach and spleen of wister rats. African Journal of Pharmaceutical Research $\&$ Development. 2019. Vol. 11 No.1. Page 35-42.

42) Babraham institute (2020). Charting immune system development in sub-Saharan African

43) Litman GW, Cannon JP, Dishaw LJ. Reconstructing immune phylogeny: new perspectives. Nature Reviews. Immunology. 2020. 5 (11): 866-79.

44) Joseph O. S., Builders M., Joseph O. T., Sabastine A. Z. Assessing differential impacts of COVID-19 on African countries: A comparative study. International Journal of Research and Innovation in Applied Science. 2020.Vol. 5, Issue 5. Page 197-203.

45) Joseph OS, Musa TL, Joseph OT, Ibhafidon I. The Dynamics of Differential Impacts of COVID-19 on African Countries Compared to Other Parts of the World. International Journal of multidisciplinary research and analysis. 2020.Volume 03 Issue 11. Page 185-198.

46) Builders M., Joseph OS, Timothy OO, Philip B. (2020). Antimalarial Drugs and COVID -19. Sumerianz Journal of Medical and Healthcare. Vol. 3, No. 12, pp. 111-116.

47) Joseph OS, Builders M, Joseph OT, Zubairu SA, Musa T. and Oyepata PJ. Sub-acute toxicity study of ethanol leaf extract of Ocimum canum on brain, lungs, stomach and spleen of wister rats. African Journal of Pharmaceutical Research \& Development 2019. Vol. 11 No.1. Page 35-42.

48) Joseph OS, Joseph OT, Musa TL and Oyepata PJ. Histological evaluation of the nephroprotective activity of the ethanol stem extracts of Homalium letestui in Gentamicin - induced albino rats injury, using various staining techniques. Global Scientific Journal. 2019. Volume 7, Issue 8. Page 1065-1087.

49) Restifo NP, Gattinoni L. Lineage relationship of effector and memory T cells. Current Opinion in Immunology. 2013.25 (5): 556-63.

50) Kurosaki T, Kometani K, Ise W. Memory B cells. Nature Reviews. Immunology. 2015. 15 (3): 149-59. 